\title{
Role of bio-fertilizers in sustainable agriculture
}

Muhammad Salman Akram¹, Muhammad Abubakar Cheema ${ }^{1}$, Muhammad Waqas ${ }^{2}$, Muhammad Bilal $^{3}$ and Muhammad Saeed ${ }^{* 1}$

${ }^{* 1}$ Centre of Agricultural Biochemistry and Biotechnology University of Agriculture, Faisalabad, Pakistan.

${ }^{2}$ Department of Plant Breeding and Genetics University of Agriculture, Faisalabad, Pakistan.

${ }^{3}$ Basic Health Unit Sarki district Muzaffargarh Pakistan

Correspondence Email: muhammadsaeed7360@gmail.com

\section{Abstract}

For years chemical fertilizers are used to fulfill the soil requirement of nutrients and yield, but large amount of these chemical fertilizers are dangerous for environment, beneficial microbes, animals, and humans as well. Therefore, environmental friendly and cost effective biofertilizers are used. Biofertilizer are the substances which contain microorganisms those microorganisms may be fungi, bacteria, and protozoa which have ability to increase fertility of soil by Nitrogen fixation, Phosphorous solubilization, and Iron sequestration. These processes convert insoluble form of nutrients into soluble form and make it available to the roots of plant which easily take them up and utilize them. There are variety of the crops whose productivity can be increased by applying biofertilizer such as rice, oat, and other grain crops. In this review we go through the way of application of biofertilizers, and how the help the plants and in which they help.

Keywords : Biofertilizers, PGPR, Auxin, Rhizobium

\section{Introduction}

By increasing population of the world the demand for the food is increasing rapidly $(1,2)$. The food demand is increasing in those developed countries where the land resources are not contributing part in crop production as the population need in daily bases needs the food requirements.to increase this capacity of land to produce more production the people first move to the application of chemical fertilizers which increase crop production. But the long application of chemical fertilizers shows adverse effects on the environment $(1,3,4)$. These chemicals accumulate in the water and also can the cause of eutrophication $(2,3)$ These chemicals also harm the soil fertility, decrease Holding capacity of soil, increases the salinity and disparity in soil nutrients (1) So the intention goes towards the bio fertilizers. These were used to decrease the bad impacts of low fertility on the soil, the impact of environmental stress and the effect of biotic stress such as pathogens and other microorganisms.(5-7). In this aspect many work has done in this field so many organic fertilizers has been introduced in these years. These work as the natural stimulators of plant growth and the development of the plants(8-10) important group of organic fertilizers were made on the basis of plant growth promoting microorganisms(PGPM). There are many groups of the microorganism which are beneficial for the plants but the major contribution are of the following three which considered as important for plants growth: arbuscular mycorrhizal fungi(10,11). Plant growth promoting rhizobacteria, and nitrogen fixing bacteria that are not considered as $\operatorname{PGPR}(4,10)$ the bio fertilizers are the material that contain living microbes that applied on seed, surfaces of plants or the soil, formation of colonies the rhizosphere or the interior of the plant, and promote the growth of the plant by increasing the supply of primary nutrients or giving the availability of these to the host $(10,12)$ The main interest going towards the application of these bio fertilizers are because of increase capacity of the nutrient uptake of the plants and he increase society of the society. $(10,13)$. Bio fertilizers are 
mostly used to increases the microbial activity which in return increases the availability of the nutrients which can be assimilated easily by the plants $(1,14,15)$ The organic fertilizers are promoted to get the natural means of getting nutrients by the plants(16) and increase the mobilization(17) which increase the fertility of the soil and increase the crop yield $(18,19)$.

\section{Why we need bio-fertilizers}

General use of chemicals as a fertilizers can full fell the demand of fast growth and high amount of food supply but obviously those leads to damage the environment (damaging microbial biota, killing friendly insects and increase in $\mathrm{pH}$ ). However the use of chemicals fertilizers make the crops susceptible to disease and also results in decease soil fertility $(5,20)$

It has been estimated the in 2020 the world population will we more than 8 billon and to feed them we need 28.8 million tons of food and nutrients and we estimated the only 21.6 million tons will be available to community of the world $)(21)$

To feed the world population we have to increase the amount of agriculture and increase the productivity in such a way the it is useful and also show no bad effect on either environment, Human, beneficial insects etc. for this purpose we have to increase agriculture productions using chemical fertilizers, pesticides, herbicides, fungicides, and insecticides (22)

As already discussed due to hazardous effect we are moving towards other sources rather the chemicals which have to be more safe and more effective and ecologically safe and cost effective as well, all these properties are present in bio-fertilizers (23).

The bio-fertilizers like other man-made chemicals are commercial products having beneficial microbes, substances important for growth of microbes and other additives which can probably increase the growth of microbes. It was reported that bio-fertilizer increase the contents of food protein, amino acids, vitamins, and nitrogen and other essential elements from renege 10\%- $40 \%$ (24)

The bio-fertilizer provides and help the plant getting both macro and micro essential elements for growth and also help in supply of hormones and other organic element for plants (25)

The application of bio fertilizer is most effective and natural way to keep the bio system active and working, the microbes in soil provides nutrients to plants and helping the biodiversity maintains by improving the quality of soil (26)

\section{How biofertilizers work:}

Bacteria, fungi and other microbes an important and unequally distributed micro-organism present everywhere in the world with different amount of concentration present in more concentration near the root and perform very important works.

The Bacteria which are present near the roots (rhizosphere) have the capability to promote plant growth accordingly are called as plant growth promoting microbes, the bacteria which play its 
role as a plant growth promoter are called as plant promoting bacteria or (PGPB). Today many of the PGPB are available on commercial scale as a bio fertilizers (27)

PGPB have very important role in the fertility of soil and plant growth. Its paly role in two way

a) PGPBs supply important hormones like auxins, cytokinin, gibberellin, which play role in plant growth directly, PGPBs help in providing the essential elements like nitrogen by nitrogen fixation, phosphorous by method of phosphorous solubilization, potassium intake, which is called as direct way.

b) Helping the genes against the pathogens in many ways which are called as indirect way.(28)

\section{Direct way of action}

\section{Auxin}

Auxin is a hormone which work in geo and phototropism, tissue differentiation, cell division, and stem root elongation (29)

PGPBs show positive effect on plant growth as they have the ability to produce the auxin, $80 \%$ microbes present in rhizosphere produce the auxin and their secondary metabolite (30)

Rhizobacteria change the level of auxin concentration in in the form of indole-3-acetic acid (IAA) which can increase the surface area of roots and large amount of uptake of auxin by plants and remember that going thought research is has been noted that auxin and IAA are interchangeable (31)

Different cells of different plants are sensitive at different level to auxin (32). Where the PGPB produce the IAA work as auxin when concentration of IAA is suboptimal roots will be develop and when optimal shoots will be $(28,33)$.

\section{Ethylene}

Ethylene is very important hormone in plant in which at play its role in both cell division and normal growth as well as also have very significant role in the helping the plant against different types of biotic and abiotic stress (34)

Almost all plant at any stage of their life are effected by ethylene which is influenced by hormones of plant, temperature, gravity, light, nutrition and various biotic and abiotic stress (28)

High concentration of ethylene help the plant to response to various stresses either temperature, chemicals like salts, or drought and light, pathogens $(35,36)$

The PGPB make bond with the roots of plants and take some of the tryptophan released by plant and change it to IAA which is then released by bacteria and taken by the plant (37)

when the amount of IAA increase it can work both as plant growth regulator and also activate the enzyme of plant ACC which increase the level of ACC and at last which results in high concentration of ethylene. The PGPBs which make IAA from the tryptophan of plant can 
promote the growth of plant as well it can inhibit the growth of plant though the ethylene production (38)

\section{Cytokinins}

Cytokinins are found in algae, bacteria, fungi and higher plants. We didn't know much about bacteria producing cytokinins and their role. Cytokinins are produced in the tip of roots and from there they are transfer to shoot though xylem. (38)

It control the cell division and differentiation in meristem cells (39)

In many PGPBs the cytokinin genes are evidenced and when they were added to plant surrounding the growth of the plant increases and as well other Phyto-hormone configuration.

When the bacteria Bacillus subtilis was used as cytokinin producing agent the results shows that the growth of plant were altered and, when the sinorhizobium melioti over produce cytokinin and which were used as tester for alfalfa plants against the drought stress. (39)

\section{Gibberellin (GA)}

Gibberellin have a group of teracyclic diterpenoid carboxylic acids with $\mathrm{C}_{20}$ or $\mathrm{C}_{19}$ (40)

Gibberellins work in the activation and stimulation of plant growth and other important process like elongation of stem, seed germination, sitting of fruit, plant flowering (41)

And also inhabit the growth of plant though GAs signaling pathway. (38)

The biochemistry of both plant produce GAs and bacteria GAs are similar and we readily absolved the absence of GAs as a reduction of side roots number and length. (42)

The pathway though which GA is produce is known in plants and fungi but in bacteria it is still unknown. (38) Bacteria Bacillus pumilus and Bacillus licheniformis are isolated which have the ability to produce GA. (43)

\section{Nitrogen fixation}

Nitrogen is an essential macroelement which is an important element required for plant growth. It is also required for the formation of nucleic acid, chlorophyll, and proteins. The nitrogen is present in the atmosphere of about $78 \%$. $(44,45)$ This is present in gaseous form so is not available for the plants. Different nitrogen fertilizers made by industries are available which increase agricultural productivity. $(38,46,47)$

Biological microbial fixation involves the conversion of the nitrogen present in the atmosphere into the form that is readily uptaken by the plants such as ammonia. $(46,48)$

The conversion of nitrogen into ammonia Need high amount of energy because of the presence of triple bond in the N2. Many nitrogen-fixing bacteria have been identified which fix the nitrogen symbiotically with the plants such as legumes. Examples are Rhizobium, 
sinorhizombium, azorhizombium etc.(7,26). Rhizobial bacteria form colonies on the root cells and start the root nodule formulation. (38). In this the bacteria act as bacteroid (having no cell wall) they fix the nitrogen by the help of nitrogenase enzyme and convert it into the ammonia.in this return the plant provides hem the fixed carbon which shows the mutualism. Different rhizobia species have been used at a commercial level to give the crop's nitrogen in the form that can they assimilate.(49)

There is side reaction in the working of nitrogenase enzyme in nitrogen cycle that is the reduction of hydrogen ion into hydrogen. which release into the atmosphere and causing the waste of energy decreasing the working of nitrogen fixation by $30 \%(38)$.

\section{Rhizobium:}

Few Nitrogen fixation sp. Are

These are nitrogen-fixing rhizobacteria and belong to the family of Rhizobacea. It includes Rhizobium, Bradyrhizobium, Sinorhizobium, Azorhizobium, and Mesorhizobium. They have mutualistic association with leguminous plant roots and those which are free living fix the nitrogen in non-leguminous plant are known as diazotrophs (50)

It is not a simple process either complex of enzyme are involved in it i.e. Nitrogenase which contains Di Nitrogenase reductase containing (Fe) iron and molybdenum (Mo) as a cofactor (51)

It convert $\mathrm{N}_{2}$ into to $\mathrm{NH}_{3}$ by using electrons and also oxygen is essential for respiration of Rhizobium sp.(4)

There are three different kinds of Nitrogenase complexes depending upon changes in cofactor of di Nitrogenase Mo- Nitrogenase, V- Nitrogenase and Fe- Nitrogenase (52)

Some genes are involved in the $\mathrm{N}_{2}$ Fixation which are called ' $\mathrm{Nf}$ 'genes they are essential for nitrogen fixation in free-living \& nitrogen-fixing organism (53)

The Nif genes are involved in the activation of Fe/Mo cofactor and also for the electron donation, biosynthesis of cofactors, and functioning and regulatory of enzymes.(54)

Experiments show that when plants were inoculated with the strain of Rhizobium wild type strain Retile 68\% more nirtogenase activity was seen, $25-30 \%$ increasing in leaf substances and seeds resultant was increase up to $16 \%$. (55)

Abeles et al 2012 also showed that when rhizobium sp was applied so the ethylene level was also inease which is one of the major plant regulators and also help in inhibiting of rhizobia infection.

\section{Azospirillum:}

Azospirillum are gram negative bacteria with ability of nitrogen fixation belong to spirilaceae family (2)

This genus include mant sp like Azospirillum amazonense, Azospirillum halopraeferens, andAzospirillum brasilense, but among them the most beneficial sp are Azospirillum lipoferum and A. brasilense (21)

They make associated symbiosis with the plants especially with those which have $\mathrm{C} 4$ dicarboxylic pathway of photosynthesis (56) 
They produce plant regulators like IAA, GA and cytokinin with work as root development due to which plants are able to uptake large amount of nutrients. (57)

The major advantage of these bacteria is that they full, fell the requirement of nitrogen in paddy, sorghum and sunflower up to $25 \%$.

\section{Azotobacter:}

They are the photoautotrophic, aerobic, non-symbiotic free-living bacteria belong to the family azotobacteriaceae, playing very important role in nitrogen cycle of plant.

They are present where soil is alkaline and most commonly arable soil (58)

Azotobacter vinelandii, Azotobacter beijerinckii, Azotobacter insignis,and Azotobacter macrocytogenes are the common sp of Azotobacor . (21)

30 Reported that Different type of hormones i.e. gibberellins, naphthalene acetic acid is produced by these bacteria which prevent the formation of root pathogen but enhance the root growth by minerals and nutrients uptake by plant. Vitamins such as vitamin B complex is also produced by these bacteria.

These type of bacteria are found in different type of crops such as rice, maize, sugarcane, vegetables (Azobactor play important role in production of some other vitamins such as riboflavin and thiamin (59)

\section{Azolla and Blue-green algae:}

Azolla contain sp Azolla caroliniana, Azolla microphylla, Azolla filiculoides, and Azolla mexicana (21).

These are present in large amount in paddy field belonging to eight different types of families and enhance the growth of plant by producing different type of hormones such as Indole acetic acid, Gibberellic acid (21).

To increase the productivity Nitrogen is essential mineral for that and that nitrogen is provided to rice plant by means of biological nitrogen fixation $(4,60)$

4-5\% of nitrogen is present in Azolla on dry basis and 0.2-0.4\% is present on wet basis. Azolla is very important means of organic fertilizer as it provide nitrogen to rice plant (21)

It also has the ability to decompose the soil fastly and also provide the plant important minerals like phosphorus, potassium iron, zinc and other micro elements, (61)

\section{Phosphate solubilization}

The bacteria which solubilize phosphorus are known as phosphate solubilizing bacteria. These bacteria $(38,62)$. These bacteria give phosphorus to the plants in the form that can be a move to the environment. These bacteria convert the phosphorus forms present in the environment such as organic and inorganic phosphate into the form which is available to the plants. These are affected by many conditions i.e. environmental, soil and also the bacterial strains present there $(63,64)$. The powerful organisms that solubilize the phosphorus are from the genera Bacillus and Rhizombim(38,65). the mechanism of solubilizing the phosphorus is firstly the utilization of mineral dissolving compounds $(66,67)$ i.e. oh ions, co 2 and other organic compounds the organic compounds then produced along with the chelates of the oh ions chelate present and cause in the decrease of $\mathrm{PH}$ in the release of the phosphorus. Then the bacteria produced organic acids and 
then the phosphate solubilizing bacteria excrete it(68) .this process cause the acidification of the microbial cell and its surroundings.

\section{Iron uptake}

Iron play different important roles in plants as a photosynthetic system, chlorophyll for light absorbance and take part in many different biosynthetic mechanisms. the iron present in soil is not sufficient for the plants. Although the iron is abundant on the earth it cannot be utilized by the plants and microbes due to its presence in insoluble form. The bacteria convert them into a soluble form by following method. They excrete molecules that bind with iron called siderophores. These molecules make bind with high affinity to iron. These soluble complexes then taken by bacteria or plants and convert it into ferrous or iron. Siderophores have low molecular weight having iron-binding groups. $(38,69,70)$

\section{Indirect methods}

Many plant diseases are causing the loss of yield of many plants of about $10 \%$ in many developed countries. (38) the scientists are promoting the PGPB in case of decrease of the chemicals.

\section{Antibiotics}

The PGPBs control the effect of many pathogen attacks by producing antibiotics that will act against the pathogen and prevent the plant from the disease. The PGPBs produce different antibiotic at different conditions. we can alter the PGPBs producing antibiotics in laboratories conditions.(71)

\section{Cell wall degrading enzymes}

Some plants produce cell wall degrading enzymes which act against fungus. for example, chitinase produced by the plants used to degrade the chitin of the fungus. The PGPBs also producing many cell wall degrading enzymes when they were studying in the lab to become an active biocontrol agent. So the PGPBs give protection to the plants by degrading the cell wall of the fungus.(43)

\section{Hydrogen cyanide}

Many PGPBs produce hydrogen cyanide. The hydrogen cyanide is used as a biocontrol agent against many diseases. The low level of the hydrogen cyanide does not allow the fungus pathogens to attack the plants. So, the PGPBs show effective resistance against the disease by producing the hydrogen cyanide. the hydrogen cyanide works by inhibiting the cytochrome $\mathrm{c}$ oxidase and its other metabolites. Many bacteria also produce $\mathrm{HCN}$ as Rhizobium, Pseudomonas, and Bacillus. $(38,72)$

\section{Application of Biofertilizer}

Increase in the growth of plants and crops:

Many applications of microbial fertilizers motivated the scientists to essay for microbes which show plant growth enhancing capabilities by increasing the nutrient standard of plants directly or indirectly (2). Some PGPR provoke the growth by representing their actions as biofertilizers. Plant growth promoting bacteria play important role in producing growth-regulating hormones. They improve the roots of plant and increase capacity of roots to take nutrients (73). For the past few years, large number of investigators have learned that PGPR has the ability to enhance crop growth and to control the plant invaders even under the greenhouse condition $(38,68)$. Biofertilizers significantly enhance the plant length, number of branches, root and shoot length 
and also collection of dry matter into the organs of plants. PGPR vary in their mechanism of action of plant growth usually influence on growth of plant through solubilization of inorganic phosphate and the production of plant growth regulators.B.megaterium the plant growth promoting bacteria enhances the growth of root and development for that reason better use of nutrient will take place (69). Biofertilizers colonize the rhizosphere of plant and enhance the growth signals \to the target crop. The Azospirillum species are known to increase the output of forage and cereal grasses by increasing the development of roots. Azospirillum proved beneficial for the plant by enhancing the nitrogen-fixing activity of bacteria in rhizosphere of plants. It helps in the development of root and shoot (74)

Increasing crop productivity:

Biofertilizers can be used as an economic input to enhance the productivity of crop; doses of fertilizers could be reduced and nutrients in high quality from soil can be harvested. The technology of production in case of biological fertilizers is simple and cost-effective in comparison to synthetic fertilizer plants.

When biofertilizers are employed as a soil inoculants they proliferate and play a role in ecological cycle of nutrients and proved helpful for the productivity of crops (75).

Growth and yield of plant have been upgraded by frequent inoculation of very potent rhizobacteria (26) and inoculation with(1).

It is reported that microorganisms such as phosphate solubilizing bacteria which we use as biofertilizer can increase the yield up to $200-500 \mathrm{~kg} / \mathrm{ha}$ and therefore superphosphate of about 30$50 \mathrm{~kg}$ can be stored.

We conducted experiments on Bray-1P and cabbage by applying chemical fertilizers and organic biofertilizers to evaluate their effects on the yield of cabbage and bray-1P.

Role of biofertilizer in photosynthesis:

Higher photosynthesis show improve growth rate of plant as about $90 \%$ of plant body is achieved through carbon dioxide assimilation by photosynthesis (76). It was announced that some strains of Rhizobia sufficiently increase the plant leaves surface area, plant rate of photosynthesis, stomatal opening and closing \& efficiency of water availability showing that the photosynthetic ability of plant can be increased by Rhizobial administration(77). Leaves are major part of plant having photosynthetic organs (chlorophyll). Therefore number of leaves are very important. Increase in number of leaves may activate the high growth of roots and also improve the transportation of water taken by plant roots and also improve the accumulation of minerals and yield (38)

Cost Effective:

Biofertilizers on action increase the soil fertility without leaving any harmful effect in the soil and they are much more cost effective.

There is a need for that agriculture system which is sustainable, in which the fertility of soil is maintained by using cost-effective resources which should be renewable such as biological fertilizers.

The need for decreasing the costs of fertilizing crops with reconvert able energy forms has revitalized the importance of biofertilizers all around the world.

Chicken manure as a biofertilizer containing a higher nitrogen content in comparison to expensive inorganic or synthetic fertilizers, easily available, hence it is easily affordable for the farmers. (2)

\section{Mode of action of bio-fertilizers}

Bio fertilizers can be applied in many ways into the soil 
- Dry biofertilizers are heterogeneous with the seeds

- Biofertilizers applied in powdered form in soil.

- A little amount of water is added into the seed hopper and then biofertilizers are add this is called ass sprinkle method.

- Biofertilizers are used in suspended form in water after that added to seeds this is called slurry method.

- Method of seed pelleting (coating the seed with biofertilizer)

- In a slurry the seed and biofertilizers are mixed and adhesive are applied and coat the seed with lime like materials.

- During the sowing the peat suspension in water sprayed into the furrow.

- Inoculation seed treatment.

- Apply in soil

- Apply in seed links or root dip.(78)

\section{Future perspective}

For the decades the development and growth of the plants were depended on the conventional methods like chemical fertilizers $(62,79,80)$

Which increase the production of yield up to a limit but they also make the environment pollute and the use of chemicals were hazardous to both human and beneficial microbes.

A review clearly brings us to the point that bio fertilizers are the sources of increasing the growth as well as nutritional amount in crops. Different types of bio fertilizer are in practice and the field of bio fertilizer is an emerging one in which many microbes are used to increase the yield of crop as well as protect it from different types of pathogens. The use of bio fertilizers are very useful and it believe that it will growth with time (81)

But in future few issues regarding bio fertilizers will need to be addressed and serious action have to be taken to solve those (28)

And also require research on the performance of different efficient stains and also their effect on other beneficial microbes and if the conditions change what will be there effect and performance.

\section{CONCLUSION}

At last of our review we concluded that today microbial based fertilizers are very significant for the improvements crop. There are two means due to which we have to use the bio fertilizers. First one that they provide the unavoidable amount of yield and nutrition to human food, they are very safe to use for both environment, plants and animals and human and highly eco-friendly. Second one is that they ensure the sustainable growth of agriculture by providing the nutrition to plant in it rhizosphere such as N, P, and K and other minerals and vitamins. Different types microbes are used for this purpose like PGPB and fungi which work exceptional well. 


\section{References}

1. Goswami M, Bhattacharyya P, Ghosh A, Das B, Bhattacharjee S, Mahanty T, et al. Biofertilizers: a potential approach for sustainable agriculture development. Environ Sci Pollut Res [Internet]. 2016;24(4):3315-35. Available from: http://dx.doi.org/10.1007/s11356-016-8104-0

2. Mahanty T, Bhattacharjee S, Goswami M, Bhattacharyya P, Das B, Ghosh A, et al. Biofertilizers: a potential approach for sustainable agriculture development. Environ Sci Pollut Res [Internet]. 2017 Feb 26 [cited 2019 Mar 24];24(4):3315-35. Available from: http://www.ncbi.nlm.nih.gov/pubmed/27888482

3. Savci S. 191-X30004. 2012;3(1):11-4. doi: 10.1093/aob/mct048

4. Santi C, Bogusz D, Franche C. Biological nitrogen fixation in non-legume plants. Ann Bot. 2013;111(5):743-67. doi: 10.1093/aob/mct048

5. Tilman D, Balzer C, Hill J, Befort BL. Global food demand and the sustainable intensification of agriculture. Proc Natl Acad Sci. 2011;108(50):20260-4. doi: 10.1073/pnas. 1116437108

6. Muraya A, Timmusk S, Muthoni J, Behers L, Aronsson A-C. Perspectives and Challenges of Microbial Application for Crop Improvement. Front Plant Sci. 2017;8(February):1-10. doi: 10.3389/fpls.2017.00049

7. Lyamlouli K, Bargaz A, Dhiba D, Chtouki M, Zeroual Y. Soil Microbial Resources for Improving Fertilizers Efficiency in an Integrated Plant Nutrient Management System. Front Microbiol. 2018;9(July). doi: 10.3389/fmicb.2018.01606

8. Arioli T, Mattner SW, Winberg PC. Applications of seaweed extracts in Australian agriculture: past, present and future. J Appl Phycol. 2015;27(5):2007-15. doi: 10.1007/s10811-015-0574-9

9. Silva MCF da, Silva EVN, Silva VSG da, Oliveira WDS, Martins MDS, Stamford NP. $<\mathrm{b}>$ Organic matter inoculated with diazotrophic bacterium Beijerinckia indica and Cunninghamella elegans fungus containing chitosan on banana "Williams" in field. Acta Sci Agron. 2017;39(1):33. doi: 10.4025/actasciagron.v39i1.30857

10. Vassilev N, Malusa E, Requena AR, Martos V, López A, Maksimovic I, et al. Potential application of glycerol in the production of plant beneficial microorganisms. J Ind Microbiol Biotechnol. 2017;44(4-5):735-43. doi: 10.1007/s10295-016-1810-2

11. Jeffries P, Gianinazzi S, Perotto S, Turnau K, Barea J-M. The contribution of arbuscular mycorrhizal fungi to plant health and soil fertility. Biol Fertil soils. 2003;37(1):1-16. doi: 10.1007/s00374-002-0546-5

12. Lugtenberg BJJ, Chin-a-woeng TFC, Bloemberg G V. Principles of Plant-Microbe Interactions. Princ Plant-Microbe Interact. 2014;(January). doi: 10.1007/978-3-31908575-3

13. Adesemoye AO, Torbert HA, Kloepper JW. Enhanced plant nutrient use efficiency with PGPR and AMF in an integrated nutrient management system. Can J Microbiol. 2008;54(10):876-86. doi: 10.1139/w08-081

14. Okur N. A Review: Bio-Fertilizers- Power of Beneficial Microorganisms in Soils. Biomed J Sci Tech Res. 2018;4(4):1-2. doi: 10.26717/bjstr.2018.04.0001076

15. Mazid M, Khan TA. Future of Bio-fertilizers in Indian agriculture: An Overview. Int J Agric Food Res. 2017;3(3):10-23 doi: 10.24102/ijafr.v3i3.132. 
16. Patle GT, Badyopadhyay KK, Kumar M. An overview of organic agriculture: A potential strategy for climate change mitigation. J Appl Nat Sci. 2018;6(2):872-9. doi: 10.31018/jans.v6i2.548

17. Aulakh CS, Ravisankar N. Organic farming in Indian context: A perspective. Agric Res J. 2017;54(2):149. doi: 10.5958/2395-146x.2017.00031.x

18. Journal AI, Dewangan HK, Pandey T, Singh S. Nanovaccine for immunotherapy and reduced hepatitis-B virus in humanized model. Artif Cells, Nanomedicine, Biotechnol [Internet]. 2018;46(8):2033-42. Available from: https://doi.org/10.1080/21691401.2017.1408118

19. Rai M, Pandit R, Gaikwad S, Kövics G. Antimicrobial peptides as natural bio-preservative to enhance the shelf-life of food. J Food Sci Technol. 2016;53(9):3381-94. doi: 10.1007/s13197-016-2318-5

20. Aktar W, Sengupta D, Chowdhury A. Impact of pesticides use in agriculture: their benefits and hazards. Interdiscip Toxicol. 2009;2(1):1-12. doi: 10.2478/v10102-0090001-7

21. Mishra D, Rajvir S, Mishra U, Kumar S. Role of Bio-Fertilizer in Organic Agriculture: A Review. Res J Recent Sci [Internet]. 2013;2(2013):39-41. Available from: http://isca.in/rjrs/archive/special_issue2012/8.ISCA-ISC-2012-1AFS-32.pdf doi: 10.1039/C3PP50325A

22. Pretty $\mathrm{J}$, Bharucha ZP. Integrated pest management for sustainable intensification of agriculture in Asia and Africa. Insects. 2015;6(1):152-82 . doi: 10.3390/insects6010152

23. Mahdi SS, Hassan GI, Samoon SA, Rather HA, Dar SA, Zehra B. Bio-fertilizers in organic agriculture. J Phytol. 2010;2(10):42-54. doi: 10.3389/fmicb.2018.01606

24. Bhardwaj D, Ansari MW, Sahoo RK, Tuteja N. Biofertilizers function as key player in sustainable agriculture by improving soil fertility, plant tolerance and crop productivity. Microb Cell Fact. 2014;13(1):1-10. doi: 10.1186/1475-2859-13-66

25. Mma Y, Mfm E. Biofertilizers and their role in management of plant parasitic nematodes. A review. E3 J Biotechnol Pharm Res [Internet]. 2014;5(1):1-6. Available from: http://www.e3journals.org doi: 10.3389/fpls.2017.00049

26. Ardakani MR, Mazaheri D, Mafakheri S, Moghaddam A. Absorption efficiency of N, P, K through triple inoculation of wheat (Triticum aestivum L.) by Azospirillum brasilense, Streptomyces sp., Glomus intraradices and manure application. Physiol Mol Biol Plants. 2011;17(2):181-92. doi: 10.1007/s12298-011-0065-7

27. Calvo P, Nelson L, Kloepper JW. Agricultural uses of plant biostimulants. Plant Soil. 2014;383(1-2):3-41. doi: 10.1007/s11104-014-2131-8

28. Gamalero E, Lingua G, Berta G, Glick BR. Beneficial role of plant growth promoting bacteria and arbuscular mycorrhizal fungi on plant responses to heavy metal stress. Can $\mathbf{J}$ Microbiol. 2009;55(5):501-14. doi: 10.1139/w09-010

29. Grobelak A, Napora A, Kacprzak M. Using plant growth-promoting rhizobacteria (PGPR) to improve plant growth. Ecol Eng [Internet]. 2015;84:22-8. Available from: http://dx.doi.org/10.1016/j.ecoleng.2015.07.019.

30. Patten CL, Glick BR. Bacterial biosynthesis of indole-3-acetic acid. Can J Microbiol. 2010;42(3):207-20. doi: 10.1139/m96-032

31. Ali B, Sabri AN, Hasnain S. Rhizobacterial potential to alter auxin content and growth of Vigna radiata (L.). World J Microbiol Biotechnol. 2010;26(8):1379-84. doi: 10.1007/s11274-010-0310-1 
32. Cheng X, Ruyter-Spira C, Bouwmeester H. The interaction between strigolactones and other plant hormones in the regulation of plant development. Front Plant Sci. 2013;4(June):1-16. doi: 10.3389/fpls.2013.00199

33. Spaepen S, Vanderleyden J, Remans R. Indole-3-acetic acid in microbial and microorganism-plant signaling. FEMS Microbiol Rev. 2007;31(4):425-48. doi: 10.1111/j.1574-6976.2007.00072.x

34. Fukami J, Cerezini P, Hungria M. Azospirillum: benefits that go far beyond biological nitrogen fixation. AMB Express [Internet]. 2018;8(1):1-12. Available from: https://doi.org/10.1186/s13568-018-0608-1

35. Ali S, Charles TC, Glick BR. Amelioration of high salinity stress damage by plant growth-promoting bacterial endophytes that contain ACC deaminase. Plant Physiol Biochem [Internet]. 2014;80:160-7. Available from: http://dx.doi.org/10.1016/j.plaphy.2014.04.003

36. Barnawal D, Bharti N, Maji D, Chanotiya CS, Kalra A. 1-Aminocyclopropane-1carboxylic acid (ACC) deaminase-containing rhizobacteria protect Ocimum sanctum plants during waterlogging stress via reduced ethylene generation. Plant Physiol Biochem [Internet]. 2012;58:227-35. Available from: http://dx.doi.org/10.1016/j.plaphy.2012.07.008

37. Glick BR. Bacteria with ACC deaminase can promote plant growth and help to feed the world. Microbiol Res [Internet]. 2014;169(1):30-9. Available from: http://dx.doi.org/10.1016/j.micres.2013.09.009

38. Olanrewaju OS, Glick BR, Babalola OO. Mechanisms of action of plant growth promoting bacteria. World J Microbiol Biotechnol [Internet]. 2017;33(11):0. Available from: http://dx.doi.org/10.1007/s11274-017-2364-9

39. De Rybel B, Mähönen AP, Helariutta Y, Weijers D. Plant vascular development: From early specification to differentiation. Nat Rev Mol Cell Biol [Internet]. 2016;17(1):30-40. Available from: http://dx.doi.org/10.1038/nrm.2015.6

40. Hedden P, Thomas SG. Gibberellin biosynthesis and its regulation. Biochem J. 2012;444(1):11-25. doi: 10.1042/bj20120245

41. Zaidi A, Ahmad E, Khan MS, Saif S, Rizvi A. Role of plant growth promoting rhizobacteria in sustainable production of vegetables: Current perspective. Sci Hortic (Amsterdam) [Internet]. 2015;193:231-9. Available from: http://dx.doi.org/10.1016/j.scienta.2015.07.020

42. Dodd IC, Zinovkina NY, Safronova VI, Belimov AA. Rhizobacterial mediation of plant hormone status. Ann Appl Biol. 2010;157(3):361-79. doi: 10.1111/j.17447348.2010.00439.x

43. Kim JS, Lee J, Lee CH, Woo SY, Kang H, Seo SG, et al. Activation of pathogenesisrelated genes by the rhizobacterium, bacillus sp. JS, which induces systemic resistance in tobacco plants. Plant Pathol J. 2015;31(2):195-201. doi: 10.5423/PPJ.NT.11.2014.0122

44. Zhang S, Gao P, Tong Y, Norse D, Lu Y, Powlson D. Overcoming nitrogen fertilizer over-use through technical and advisory approaches: A case study from Shaanxi Province, northwest China. Agric Ecosyst Environ [Internet]. 2015;209:89-99. Available from: http://dx.doi.org/10.1016/j.agee.2015.03.002

45. Zhang S, Moyne AL, Reddy MS, Kloepper JW. The role of salicylic acid in induced systemic resistance elicited by plant growth-promoting rhizobacteria against blue mold of tobacco. Biol Control. 2002;25(3):288-96. doi: 10.1016/S1049-9644(02)00108-1 
46. Sathya A, Krishnamurthy L, Vijayabharathi R, Gowda CLL, Varshney RK, Gopalakrishnan S. Plant growth promoting rhizobia: challenges and opportunities. 3 Biotech. 2014;5(4):355-77. doi: 10.1007/s13205-014-0241-X

47. Xu X, Li Y, Liang Y, Yin M, Yu Z, Zhang Y, et al. MiR-18a and miR-17 are positively correlated with circulating PD-1 + ICOS + follicular helper T cells after hepatitis B vaccination in a chinese population. 2018;1-8. doi: 10.1016/j.scienta.2015.07.020

48. Winitsky SO, Gopal T V., Hassanzadeh S, Takahashi H, Gryder D, Rogawski MA, et al. Adult murine skeletal muscle contains cells that can differentiate into beating cardiomyocytes in vitro. PLoS Biol. 2005;3(4):0662-71. doi: 10.1371/journal.pbio.0030087

49. Science FOF, Campus M. ISOLATION OF BACTERIAL STRAINS FOR IMPROVED MAIZE PRODUCTION BY OLUWASEYI SAMUEL OLANREWAJU A dissertation submitted in fulfilment of the requirements for the degree of MASTER OF SCIENCE ( BIOLOGY ) DEPARTMENT OF BIOLOGICAL SCIENCES FACULTY OF SCIENCE , A. 2016;(November). doi: 10.4025/actasciagron.v39i1.30857

50. Verma C. A Review on Impacts of Genetically Modified Food on Human Health. Open Nutraceuticals J [Internet]. 2011;4(1):3-11. Available from :http://benthamopen.com/ABSTRACT/TONUTRAJ-4-3 doi: 10.2174/1876396001104010003

51. Hoffman BM, Lukoyanov D, Yang Z-Y, Dean DR, Seefeldt LC. Mechanism of Nitrogen Fixation by Nitrogenase: The Next Stage Supplemental Materials. Chem Rev [Internet]. 2014;114(8):4041-62. Available from:

http://www.ncbi.nlm.nih.gov/pubmed/24467365\%0Ahttp://www.pubmedcentral.nih.gov/a rticlerender.fcgi?artid=PMC4012840\%0Ahttp://pubs.acs.org/doi/10.1021/cr400641x

52. Yang ZY, Danyal K, Seefeldt LC. Mechanism of mo-dependent nitrogenase. Methods Mol Biol. 2011;766:9-29. doi: 10.1007/978-1-61779-194-9_2

53. Black M, Moolhuijzen P, Chapman B, Barrero R, Howieson J, Hungria M, et al. The genetics of symbiotic nitrogen fixation: Comparative genomics of 14 rhizobia strains by resolution of protein clusters. Genes (Basel). 2012;3(1):138-66. doi: 10.3390/genes3010138

54. Ahemad M. Enhancing phytoremediation of chromium-stressed soils through plantgrowth-promoting bacteria. J Genet Eng Biotechnol [Internet]. 2015;13(1):51-8. Available from: http://dx.doi.org/10.1016/j.jgeb.2015.02.001

55. Glick BR. Beneficial plant-bacterial interactions. Beneficial Plant-Bacterial Interactions. 2015. 1-243 p. doi: 10.1007/s11356-016-8104-0

56. Mishra P, Dash D. Rejuvenation of Biofertiliser for Sustainable Agriculture Economic Development (SAED). Cons J Sustain Dev [Internet]. 2014;Vol. 11(1):41-61. Available from: http://www.consiliencejournal.org/index.php/consilience/article/viewFile/350/176

57. Trabelsi D, Mhamdi R. Microbial Inoculants and Their Impact on Soil Microbial Communities: A Review. Biomed Res Int. 2013;2013:1-11. doi: 10.1155/2013/863240

58. Biosci IJ, Moraditochaee M, Azarpour E, Bozorgi HR. Study effects of bio-fertilizers , nitrogen fertilizer and farmyard manure on yield and physiochemical properties of soil in lentil farming Department of Agriculture, College of Agricultural Science, Takestan Branch, Islamic Azad. 2014;6655:41-8.

59. Wani S, Chand S, Ali T. Potential Use of Azotobacter chroococcum in Crop Production: An Overview. Curr Agric Res J. 2013;1(1):35-8. doi: 10.12944/carj.1.1.04 
60. Sharma P, Sharma P, Devi G, Sharma M, Masthigowda Mamrutha H, Venkatesh K, et al. Biological nitrogen fixation in cereals: An overview. J Wheat Res [Internet]. 2016;8(2):111. Available from: http://epubs.icar.org.in/ejournal/index.php/JWR

61. Ghany A, Abboud A. Role of biofertilizers in agriculture: a brief review. Mycopath. 2013;11(2):95-101.

62. Alori ET, Glick BR, Babalola OO. Microbial phosphorus solubilization and its potential for use in sustainable agriculture. Front Microbiol. 2017;8(JUN). doi:

10.3389/fmicb.2017.00971

63. Numan M, Bashir S, Khan Y, Mumtaz R, Shinwari ZK, Khan AL, et al. Plant growth promoting bacteria as an alternative strategy for salt tolerance in plants: A review. Microbiol Res [Internet]. 2018;209(February):21-32. Available from: https://doi.org/10.1016/j.micres.2018.02.003

64. Williams AR, Hare JM. Mesenchymal stem cells: Biology, pathophysiology, translational findings, and therapeutic implications for cardiac disease. Circ Res. 2011;109(8):923-40. doi: 10.1161/CIRCRESAHA.111.243147

65. Vurro M, Bonciani B, Vannacci G. Emerging infectious diseases of crop plants in developing countries: Impact on agriculture and socio-economic consequences. Food Secur. 2010;2(2):113-32. doi: 10.1007/s12571-010-0062-7

66. Saharan BS, Nehra V, BS Saharan VN. Plant Growth Promoting Rhizobacteria : A Critical Review. Life Sci Med Res [Internet]. 2011;21:1-30. Available from: http://astonjournals.com/manuscripts/Vol2011/LSMR-21_Vol2011.pdf

67. Saha M, Bhattacharjee S, Sharma BK, Sarkar B, Tribedi P, Sarkar S. Microbial siderophores and their potential applications: a review. Environ Sci Pollut Res. 2015;23(5):3984-99. doi: 10.1007/s11356-015-4294-0

68. Zafar-ul-Hye M, Ahmad M, Shahzad SM. Synergistic effect of rhizobia and plant growth promoting rhizobacteria on the growth and nodulation of lentil seedlings under axenic conditions. Soil Environ. 2013;32(1):79-86.

69. Dalcorso G, Manara A, Furini A. An overview of heavy metal challenge in plants: From roots to shoots. Metallomics. 2013;5(9):1117-32. doi: 10.1039/c3mt00038a

70. Ganz T. Systemic Iron Homeostasis. Physiol Rev. 2013;93(4):1721-41. doi: 10.1152/physrev.00008.2013

71. Devine A, Harvey R, Min AM, Gilder MET, Paw MK, Kang J, et al. Strategies for the prevention of perinatal hepatitis $\mathrm{B}$ transmission in a marginalized population on the Thailand-Myanmar border : a cost-effectiveness analysis. 2017;1-10. doi: 10.1186/s12879-017-2660-X

72. Ramette A, Moënne-Loccoz Y, Défago G. Genetic diversity and biocontrol potential of fluorescent pseudomonads producing phloroglucinols and hydrogen cyanide from Swiss soils naturally suppressive or conducive to Thielaviopsis basicola-mediated black root rot of tobacco. FEMS Microbiol Ecol. 2006;55(3):369-81. doi: 10.1111/j.15746941.2005.00052.x

73. Ji SH, Kim JS, Lee CH, Seo HS, Chun SC, Oh J, et al. Enhancement of vitality and activity of a plant growth-promoting bacteria (PGPB) by atmospheric pressure nonthermal plasma. Sci Rep [Internet]. 2019;9(1):1-16. Available from: http://dx.doi.org/10.1038/s41598-018-38026-z

74. Simarmata T, Turmuktini T, Fitriatin BN, Setiawati MR. Application of Bioameliorant and Biofertilizers to Increase the Soil Health and Rice Productivity. HAYATI J Biosci. 
2017;23(4):181-4. doi: 10.1016/j.hjb.2017.01.001

75. Wang J, Panáková D, Kikuchi K, Holdway JE, Gemberling M, Burris JS, et al. The regenerative capacity of zebrafish reverses cardiac failure caused by genetic cardiomyocyte depletion. Development [Internet]. 2011;138(16):3421-30. Available from: http://dev.biologists.org/lookup/doi/10.1242/dev.068601

76. Malusá E, Sas-Paszt L, Ciesielska J. Technologies for Beneficial Microorganisms Inocula Used as Biofertilizers. Sci World J. 2012;2012:1-12. doi: 10.1100/2012/491206

77. K P S, R SB. Integrated plant nutrient system - with special emphasis on mineral nutriton and biofertilizers for Black pepper and cardamom - A review. Crit Rev Microbiol [Internet]. 2015;00(00):1-15. Available from: http://dx.doi.org/10.3109/1040841X.2014.958433

78. Bashan Y. Inoculatnt of plant growh promoting bacteria for use in agriculture Pll S07349750(98)00003-2 ELSEVIER. 1998;16(4):729-70.

79. Philippot L, Raaijmakers JM, Lemanceau P, Van Der Putten WH. Going back to the roots: The microbial ecology of the rhizosphere. Nat Rev Microbiol [Internet]. 2013;11(11):78999. Available from: http://dx.doi.org/10.1038/nrmicro3109

80. Zemla M, Singh S, Varanasi P, Simmons BA, Singer SW, Eichorst SA, et al. Community dynamics of cellulose-adapted thermophilic bacterial consortia. Environ Microbiol. 2013;15(9):2573-87. doi: 10.1111/1462-2920.12159

81. Weekley J, Gabbard J, Nowak J. Micro-Level Management of Agricultural Inputs: Emerging Approaches. Agronomy. 2012;2(4):321-57. doi: 10.3390/agronomy2040321 